\title{
Evaluation of Use of Consortium of e-Resources in Agriculture in Context of Kerala Agricultural University
}

\author{
A.T. Francis \\ Kerala Agricultural University, Thrissur-680 656 \\ E-mail: francisaloor@yahoo.com
}

\begin{abstract}
As digital information resources available online are increasing at an exponential rate, several practices have evolved for the economic and effective delivery of such information to the end users. In this context, consortia-based information services have gathered momentum world over during the last few years. Though, there are several library consortia in India, UGC Infonet is mainly meant for universities controlled by UGC and CeRA is meant for agricultural universities. This paper discusses utilisation of consortia-based digital information resources by the post graduate and doctoral students of the Kerala Agricultural University, Thrissur. Results show that cent percent of the students were familiar with the use of digital information resources available online and 87.14 per cent of them used CeRA. Eighty two per cent students were acquainted with CeRA and learned the required skills for the access and use of digital information resources through curriculum-based courses like 'library and information services', 'research methodology', etc. The students in general would like to strengthen the CeRA services by adding more resources and facilities.
\end{abstract}

Keywords: Digital resources, internet, e-journals consortia, university library

\section{INTRODUCTION}

Technologically speaking, several experiments, innovations, and practices were tested in the field of publishing of journals and their access by the libraries. The advent of electronic or digital journals, online journals, magazines, etc., have necessitated a thorough redefining of the serials control system of the libraries as online magazines or journals are disseminated through internet websites. The information and communication technologies have made radical changes in the conventional system of information processing and its delivery and most of the universities offer courses in their multiple campuses and also through their affiliated or recognised colleges/institutions. In many universities, courses are extensively being offered through distance education mode also. Though academic libraries have begun to build impressive portfolios of online services and programmes for remote users, little notice is paid to whether or not the initiatives are useful, successful, or whether targeted users are even aware of their availability. Indian universities constitute one of the largest higher education systems in the world. Although, it is a great challenge to ensure effective coordination and communication, several programmes have already started in India to provide a seamless supply of information resources by way of access to journals and databases, course materials, online lectures, etc., in electronic format to the academic and research community. The UGC, ICAR, AICTE, National Knowledge Commission, National Knowledge Network, National Innovation Council, etc., have done leading roles towards this end.

As the universities in India are broadly controlled by two agencies like UGC and ICAR, the library and information resources management and services are also performed differently. While the universities under UGC have formed UGC Infonet for consortia mode of journal subscription and electronic information services, the agricultural universities and agricultural research institutes formed CeRA ${ }^{1}$ for the same purpose. Moreover, there are several other consortia also in operation in India for institutions under CSIR, DRDO, IITs, IIMs, etc.

\subsection{Kerala Agricultural University}

The Kerala Agricultural University (KAU) was established by the Act 33 of 1971 of the Kerala State Legislature, with a mission to achieve excellence in agricultural education, research and extension for 
sustainable agricultural development and livelihood security of farming community. Its goal is to provide human resources, skills and technology required for sustainable development of agriculture, including crop production, animal husbandry, veterinary sciences, dairy sciences \& technology, co-operation, fisheries, forestry, agricultural engineering, home science and other allied disciplines by integrating education, research, and extension. The University fulfills its obligations and commitments through a network of institutions spread over 36 campuses through the length and breadth of the state, consisting of ten constituent colleges, six regional agricultural research stations, 26 research stations, three centres of advanced studies, seven Krishi Vigyan Kendras and various other research programmes. It has a three-tier system of libraries comprising of the university library at the top. College and research station libraries are in the second and third levels, respectively.

\section{OBJECTIVES OF STUDY}

The purpose of the study was to explore the awareness and usage of consortia-based information and knowledge resources by the post graduate $(P G)$ and doctoral students of KAU. The main objectives were to:

- Evaluate the pattern of access and use of digital resources by the PG and doctoral students

- Find out the purposes for which the digital resources were used

- Assess the impact of consortia-based delivery of digital resources

- Know the adequacy of resources available through the CeRA

- Assess the provision and impact of user education and information literacy courses for PG and doctoral students

- Suggest suitable measures to improve the consortiabased delivery of digital resources

\subsection{Scope and Limitation}

The study is based on the user behaviour and the pattern of the utilisation of information resources by the $P G$ and doctoral students of KAU. The scope of the study is limited to the digital resources mainly available through CeRA and in KAU.

\subsection{Review of Literature}

Information resources in the form of journals occupy a pivotal position in any university or research library. The citation analysis of doctoral dissertation in chemistry reveals that the researchers mainly depend on periodicals for their information use ${ }^{2}$. A proper control and management of journals is important for meeting the users' needs effectively. The two major problems associated with the serials management are the multiplication of number of journals published and the steep increase in their prices. Based on a survey on more than 8000 scholarly journals of leading international publishers, White and Creaser ${ }^{3}$ reported that journal prices are estimated to have increased by 39 per cent between 2001 and 2006, while the retail price index has risen by 16 per cent over the same period ${ }^{3}$. Such crucial situations coupled with paucity of funds forced the libraries to try out several experiments and adopt new practices in the area of acquisition, management, and servicing of journals. The composition of the journal collection of libraries has changed dramatically. The percentage of print-only subscriptions decreased and ejournals jumped to high. The proliferation of e-resources had a major impact on the acquisition activities right from handling physical objects to initiating and ensuring ongoing access to e-resources. It has resulted in a workflow that requires an ongoing review and change in order to accommodate the constant technological developments that have impacted the management of information delivered electronically. In order to scientifically move the library from a predominantly print environment to a predominantly electronic environment, the management processes have been re-engineered ${ }^{4}$. According to VijayaKumar and Vijayakumar ${ }^{5}$, though e-journals created several technological and social issues, it provided better facilities in terms of accessibility, speed of distribution and production, subscription cost, multimedia capabilities, etc.

One major collateral blessing to emerge from the rise of online information is the incentives that it offers to libraries to work together for mutual benefit. This can best be seen in the very active effort exerted by many library consortia to obtain group pricing for their members for electronic information products. Vendors have been very receptive to these because it significantly lessens the amount of marketing costs that they would have to bear to prepare their case in each individual library. The difference between buying it alone and buying through a consortium can be very vast and is particularly useful for libraries that already license a product without such a discount. Those who have not licensed products for cost reasons may well find themselves able to do so. The library economizes in the first case and expands its services in the second; there is an economic benefit to both of these ${ }^{6}$. The e-journals service of the UGC Infonet is very popular amongst the scholarly community and was sought after by universities and colleges, who do not have the benefit of access to e-resources through the programmes. The UGC Infonet Services have now been extended to more than 200 universities and six inter-university centres.

Bostick ${ }^{7}$ argued that the buying power of the libraries for better prices has increased under the consortia mode. 
In the present system of multi-disciplinary education, research, and extension, it is a fact that all journals and databases are relevant to all universities with varied degree of interest. In the broader sense, though the areas of interest are similar and the major funding agency for these consortia is Central and State Governments in India, several consortia activities by different agencies are taking place in the country. This causes duplication of efforts and increase in costs and inefficiency ${ }^{8}$. Libraries outside the stream of agriculture hold very important and otherwise not available information on agriculture, which is original, traditional and sustainable ${ }^{9}$.

\subsubsection{Partnerships and Resource Sharing}

As no library in the world is self-reliant, collaboration and active partnership are the order of the day to win maximum benefits. There are several good partnerships in the LIS field. AgNIC ${ }^{10}$, (Agriculture Network Information Centre) stands as one of National Agricultural Library (NAL) strongest and broadest partnerships extended to members around the world. Today, with technology rapidly advancing and budgets shrinking almost as fast, these partnerships are more important than ever. They provide a broad range of cost savings, including leveraging resources, sharing skills and collaborating on projects. Each partner brings something to the table and also benefits from the outcome.

Though co-operation and partnership is the perfect need of the day, most of the libraries or universities in India are not able to develop even OPACs or Web OPACs of all books, journals and other information resources available in their universities. This situation has practically denied the possibilities of library cooperation and resource sharing between universities and research institutions in India though ICTs offers an immense scope for such programmes. As most of the university libraries have memberships in library consortia and library networks and they claim the provision for inter-library loan services, only small percentage of the users have knowledge about such services. This underlines the need for re-engineering and re-defining the partnerships between libraries and strengthen inter-library loan services. Institutional tie-ups with other libraries and networks, intensified user education and training programmes and adoption of latest ICTs and web technologies for digital document delivery, strengthening the ICT competency of the library and information professionals, etc., are few basic areas need re-defining and re-engineering to strengthen the service.

\subsubsection{Library Website as a Clearing Centre of Information}

One of UNESCO's ${ }^{11}$ priorities is to promote universal access to information and to strengthen communication capacities at the local level. It emphasises the importance of websites for effective access of information resources available world over. Several universities and libraries have already adopted the library website as an important tool for information delivery. Library users also prefer to avail information services through the library websites. As websites becoming important means for information services, it is essential to design the websites with utmost care and effectiveness. Hence, many libraries have changed their websites into content management system. Library websites should employ technical skills to transform them as a proper clearing centre of information. In this role, the librarian has to function as Web content manager. Corcoran ${ }^{12}$ stated that, even though the library spends a huge amount of money on resources, and if a user has inability or difficulty in accessing them and as a result does not use them, the money has been wasted.

Lebowitz ${ }^{13}$ observed that, "Although many consider the library to be the heart of the university, the use of the library is often not incorporated into courses being prepared for distance delivery .... as academic institutions extend their educational offerings beyond the campus, to rural, suburban, and urban locations, they need to consider... the role that the library plays in the educational process". She recommends that librarians convince fellow educators and administrators that as they are expanding their institutions' educational offerings beyond the campus boundaries, they need to provide their students with access to library services, which include among others, instruction in use of resources, document delivery, and communication facility between the students and librarian. Studies on the libraries in Kerala State revealed that several issues have to be addressed by the libraries in order to meet the information needs of the users. Among these issues were: the need to have more information resources available online that can be accessed remotely, effective inter-library and digital document delivery services, strengthening of information literacy and user education programmes with stress on ICTs, retrieval software and search tools, and reengineering the management of human resources of libraries ${ }^{14}$.

\section{METHODOLOGY ADOPTED}

The study was conducted among the PG and research students of KAU. As the colleges of KAU are spread over the entire state of Kerala, for the convenient and effective execution of the study, out of a total of 10 constituent colleges of the university, only five colleges situated in the central part of the state and offering PG and/or doctoral courses have been covered for the study. These colleges were: College of Horticulture $(\mathrm{CoH})$, College of Forestry (CoF), College of Co-operation, Banking and Management (CCBM), Kelappaji College of Agricultural Engineering and Technology (KCAET) and 
College of Veterinary and Animal Sciences Mannuthy (COVAS). These colleges offer courses like BSc (Hons)Agriculture; MSc-Agriculture/Forestry/Co-operation \& Banking/Biotechnology/Climate Change; BVSc; MVSc; BTech/MTech-Agricultural Engineering; MBA-Agricultural Business Management; and PhD-Agriculture/ Horticulture/Home Science/Biotechnology/Forestry and Wild Life/Rural Banking/ Marketing/Veterinary and Animal Sciences, etc.

Data was mainly collected using a pre-structured interview schedule. As a course teacher of 'library and information services'; and 'research methodology' for the $P G$ and doctoral courses of the university, the investigator has made additional discussions with the students and enriched the data thus collected. The data was collected from total 140 PG and PhD students admitted during 2008-10, tabulated, and analysed.

\section{ANALYSIS AND INTERPRETATIONS}

The distribution of students according to their disciplines/subjects areas is given in the Table 1.

Table 1. Distribution of respondents according to discipline or subject

\begin{tabular}{|c|c|c|}
\hline \multirow[b]{2}{*}{$\begin{array}{l}\text { S. Courses/Subject } \\
\text { No. }\end{array}$} & \multicolumn{2}{|c|}{ Admissions } \\
\hline & $\begin{array}{c}\text { PG } \\
(2008-2010)\end{array}$ & $\begin{array}{c}\text { PhD } \\
(2008-2010)\end{array}$ \\
\hline 1. Agri-Business Management & 18 & 00 \\
\hline 2. Agricultural Economics & 05 & 01 \\
\hline 3. Agricultural Engineering & 10 & 00 \\
\hline 4. Agricultural Entomology & 05 & 01 \\
\hline 5. Agricultural Extension & 05 & 01 \\
\hline 6. Agricultural Meteorology & 01 & 00 \\
\hline 7. Agricultural Statistics & 01 & 00 \\
\hline 8. Agronomy & 05 & 00 \\
\hline 9. Co-operation and Banking & 02 & 00 \\
\hline 10. Forestry & 09 & 01 \\
\hline 11. Home Science & 06 & 01 \\
\hline 12. Olericulture & 06 & 01 \\
\hline 13. Plant Biotechnology & 06 & 00 \\
\hline 14. Plant Breeding \& Genetics & 05 & 01 \\
\hline 15. Plant Pathology & 05 & 01 \\
\hline 16. Plant Physiology & 01 & 01 \\
\hline 17. Plantation Crops \& Spices & 03 & 00 \\
\hline 18. Pomology \& Floriculture & 06 & 01 \\
\hline 19. Processing Technology & 04 & 00 \\
\hline $\begin{array}{l}\text { 20. Soil Science \& Agricultural } \\
\text { Chemistry }\end{array}$ & 06 & 01 \\
\hline $\begin{array}{l}\text { 21. Veterinary and Animal } \\
\text { Science }\end{array}$ & 19 & 01 \\
\hline Total & 128 & 12 \\
\hline
\end{tabular}

\subsection{Expertise in Computer and IT Tools}

Table 2 shows the distribution of students according to their expertise in computer and IT tools. It is observed that all students have familiarity with computer and IT tools. 51.43 per cent students were moderately familiar, 32.86 per cent were familiar and 15.71 per cent were highly familiar.

Table 2. Expertise of students in computer and IT tools

\begin{tabular}{lll}
\hline Expertise in computer and IT tools & No. & $\%$ \\
\hline Highly familiar & 22 & 15.71 \\
Familiar & 46 & 32.86 \\
Moderately familiar & 72 & 51.43 \\
Not familiar & 00 & 00.00 \\
\hline Total & 140 & 100 \\
\hline
\end{tabular}

\subsection{Use of Digital Information Resources}

It is evident from Table 3 that while all students were using internet-based information resources, the online journals, CD-ROM databases and online databases were used by 91.43 per cent, 69.29 per cent and 25.71 per cent students, respectively.

Table 3. Use of digital information resources

\begin{tabular}{lll}
\hline Use of digital information resources & Responses & $\%$ \\
\hline Internet-based resources available through & 140 & 100 \\
Google, Google Scholar, Yahoo, etc. & & \\
Online journals & 128 & 91.43 \\
CD-ROM databases & 97 & 69.29 \\
Online databases & 36 & 25.71 \\
\hline
\end{tabular}

\subsection{Locations of Accessing Electronic Resources}

Table 4 highlights the most favoured location from where the electronic resources were accessed by the students. A majority of them (61.43\%), accessed the resources from the computer centre of the colleges and next is college libraries (18.57\%). The other locations were university library $(10.71 \%)$, hostels $(6.43 \%)$, and home and internet café (1.43\%) each.

Table 4. Locations of accessing e-resources

\begin{tabular}{lll}
\hline Locations of access & No. & $\%$ \\
\hline Computer centre of the college & 86 & 61.43 \\
College library & 26 & 18.57 \\
University library & 15 & 10.71 \\
Hostel & 09 & 06.43 \\
Home & 02 & 01.43 \\
Internet café & 02 & 01.43 \\
\hline Total & 140 & 100 \\
\hline
\end{tabular}




\subsection{Access and Use of Digital Information Resources}

The distribution of students according to their method of access and use of digital information resources is shown in Table 5. It has been observed that while all students were accessing and using information resources freely available through the internet, the resources available through CeRA were used by 87.14 per cent of students. Librarysubscribed online resources were used by 85.71 per cent and CD-ROM database resources available in the libraries were used by 65 per cent of the students.

Table 5. Method of access and use of digital information resources

\begin{tabular}{lrr}
\hline Method of access & No. & $\%$ \\
\hline $\begin{array}{l}\text { Resources freely available through internet using } \\
\text { Google, Google Scholar, Yahoo, etc. }\end{array}$ & 140 & 100 \\
Resources available online through CeRA & 122 & 87.14 \\
Resources subscribed online through KAU libraries & 120 & 85.71 \\
CD-ROM database resources available in KAU libraries & 91 & 65 \\
\hline
\end{tabular}

\subsection{Frequency of Access and Use of CeRA Resources}

The distribution of respondents according to the frequency of access and use of CeRA resources is shown in Table 6. It is evident that 36.07 per cent students were accessing and using CeRA resources many times in a week, 28.68 per cent once in a week, 10.66 per cent daily, 9.83 per cent many times in a month, 8.20 per cent once in a month and only 6.56 per cent were occasional users.

Table 6. Frequency of access and use of CeRA resources

\begin{tabular}{llc}
\hline Frequency of Access & No. & $\%$ \\
\hline Daily & 13 & 10.66 \\
Many times in a week & 44 & 36.07 \\
Once in a week & 35 & 28.68 \\
Many times in a month & 12 & 09.83 \\
Once in a month & 10 & 08.20 \\
Occasional & 08 & 06.56 \\
\hline Total & 122 & 100 \\
\hline
\end{tabular}

\subsection{Method of Access and Use of CeRA Resources}

Table 7 shows that 88.52 per cent students accessed and used CeRA full text resources and 11.48 per cent used abstracts only. 66.39 per cent respondents requested articles and 30.33 per cent respondents received articles through the Document Delivery System of the CeRA.

\subsection{Learning to Access and Use of CeRA Resources}

The distribution of respondents according to the methods of learning access and use of CeRA resources is shown in Table 8. 63.12 per cent students learned accessing and using CeRA resources through curriculumbased 'Library and Information Service' or 'Research Methodology' courses. 18.85 per cent students were learned through curriculum-based course with additional guidance from the library staff. 13.93 per cent and 4.1 per cent of the students learned the use of CeRA by self study, and from class mates and friends, respectively.

Table 8. Methods of learning access and use of CeRA resources

\begin{tabular}{|c|c|c|c|c|c|c|}
\hline Respondents & Co & CoF & $\begin{array}{l}\text { CC } \\
\text { BM }\end{array}$ & $\begin{array}{l}\text { KC } \\
\text { AET }\end{array}$ & $\begin{array}{l}\text { CO } \\
\text { IVAS }\end{array}$ & $\begin{array}{l}\text { Total No. } \\
\quad(\%)\end{array}$ \\
\hline Self study & 04 & 00 & 00 & 00 & 01 & $05(04.10)$ \\
\hline From class mates and friends & 08 & 01 & 06 & 00 & 02 & $17(13.93)$ \\
\hline $\begin{array}{l}\text { Through curriculum-based } \\
\text { library and information service } \\
\text { /research methodology course }\end{array}$ & 49 & 07 & 02 & 09 & 10 & $77(63.12)$ \\
\hline $\begin{array}{l}\text { Through curriculum-based } \\
\text { course as above with additiona } \\
\text { guidance from the library staff }\end{array}$ & $\mathrm{al}^{19}$ & 02 & 00 & 01 & 01 & $23(18.85)$ \\
\hline Guidance from computer staff & 00 & 00 & 00 & 00 & 00 & 00 \\
\hline $\begin{array}{l}\text { Other training offered by the } \\
\text { college/university }\end{array}$ & 00 & 00 & 00 & 00 & 00 & 00 \\
\hline Total & 80 & 10 & 08 & 10 & 14 & 122 \\
\hline
\end{tabular}

\subsection{Adequacy of Information Resources available through CeRA}

The distribution of $P G$ students and research scholars indicating the adequacy of digital information resources is given in Table 9. It is evident that 39.34 per

Table 7. Method of access and use of CeRA resources

\begin{tabular}{|c|c|c|c|c|c|}
\hline $\begin{array}{l}\text { Respondents } \\
\text { college-wise }\end{array}$ & Total No. & Abstracts only & Abstracts and full-text & Requested articles & Articles received \\
\hline$\overline{\mathrm{CoH}}$ & 80 & 00 & 80 & 61 & 32 \\
\hline $\mathrm{CoF}$ & 10 & 02 & 08 & 05 & 01 \\
\hline ССВM & 08 & 06 & 02 & 01 & 00 \\
\hline KCAET & 10 & 00 & 10 & 10 & 03 \\
\hline COVAS & 14 & 06 & 08 & 04 & 01 \\
\hline
\end{tabular}


Table 9. Adequacy of CeRA resources

\begin{tabular}{llc}
\hline Opinion & No. & $\%$ \\
\hline Adequate resources available & 48 & 39.34 \\
Some time adequate & 74 & 60.66 \\
\hline Total & 122 & 100 \\
\hline
\end{tabular}

cent of the students felt that adequate resources were available through CeRA.

\subsection{Problems faced in accessing and using CeRA}

The problems faced by the students in the effective use of CeRA resources are indicated in Table 10. Inadequacy of digital resources and expertise in search tools, low speed of internet, limitation in the night functioning of library/computer centre, non-availability of union catalogue of resources, etc., were the major problems identified.

Table 10. Problems in accessing and using CeRA

\begin{tabular}{lcc}
\hline \multicolumn{1}{c}{ Problems } & Responses & $\%$ \\
\hline Many essential resources not available & 79 & 64.75 \\
$\begin{array}{l}\text { Difficulty in locating most relevant resources } \\
\text { due to less expertise in search tools }\end{array}$ & 73 & 59.84 \\
Low speed of internet & 72 & 59.02 \\
Limitation in the night working of & 69 & 56.56 \\
library/computer centre & & \\
Abstracting and statistics not available & 51 & 41.80 \\
Difficulty in finding relevant information & 43 & 35.25 \\
Theses not available & 37 & 30.33 \\
More journals should be added & 29 & 23.77 \\
Non-availability of union catalogue of books & 23 & 18.85 \\
and journals of all libraries & & 17.21 \\
Inadequate computer terminals & 21 & 16.39 \\
Request article service should be strengthened & 20 & 13.93 \\
Many unwanted resources available & 17 & \\
\hline
\end{tabular}

\section{FINDINGS}

The following are the major observations based on the study:

- All PG students and research scholars were familiar with the use of digital resources. The students using internet based information resources, online journals, CD-ROM databases and online databases were 100 per cent, 91.43 per cent, 69.29 per cent, and 25.71 per cent respectively. Their preferred location to access the digital information resources is the computer centre and then college and university libraries.

- While all students were accessing and using information resources freely available through internet; resources available through CeRA were used by 87.14 per cent students. Library-subscribed online resources were used by 85.71 per cent and CD-ROM database resources available in the libraries were used by 65 per cent students. 36.07 per cent of the students were accessed and used CeRA resources many times in a week, 28.68 per cent once in a week and 10.66 per cent daily.

- Most of the students (88.52\%) accessed and used full-text resources of CeRA, and 11.48 per cent used only abstracts. 66.39 per cent of the respondents requested articles and 30.33 per cent received articles through the document delivery system of the CeRA.

- Majority of the students (63.12\%) knew the required skills for accessing and using CeRA resources through curriculum-based 'library and information service' or 'research methodology' courses. 18.85 per cent students received additional guidance and support from the library staff. 13.93 per cent and 4.1 per cent students learned the use of CeRA by self study, and from class mates and friends, respectively;

- While 39.34 per cent students felt that adequate resources were available through CeRA, 60.66 per cent indicated about, 'Some time adequate' resources.

- Major problems faced while using CeRA were nonavailability of many essential resources, difficulty in locating relevant resources due to less expertise in search tools, low-speed of internet, limitation in the night working of library/computer centre, nonavailability abstracting and statistics databases, nonavailability of union catalogue of resources, difficulty in finding relevant information, etc.

\section{RECOMMENDATIONS}

The following recommendations are made to improve the access and use of digital information resources and CeRA by the $P G$ and doctoral students:

- Consortia-based digital information services should be strengthened by adding more resources like journals, books, databases, theses, reports, union catalogue of all information documents available in all libraries. The document delivery service should be more effective and inter-consortia services between other consortiums maintained by agencies like ICAR, UGC, CSIR, DRDO, IITs, IIMs, etc., can be considered.

- Information literacy and user education courses with emphasis on retrieval software, tools and techniques of searching, etc., should be provided to all categories of the users. Adequate practical sessions should be included in such courses. 
- High speed internet, more computer terminals, round the clock service of the libraries and computer centres, web OPAC and other supportive information for inter-library services in the library websites, etc., should be provided by the universities/colleges.

\section{CONCLUSIONS}

The exponential growth of digital information resources has necessitated consortia-based services for the economic and effective delivery of information to the end users. CeRA of ICAR has become a heavily-used service by the students. Curriculum-based information literacy courses like 'library and information services', 'research methodology', etc., have contributed much towards imparting required skills for the access and use of digital information resources. Strengthening of CeRA services by adding more resources and facilities will provide strong information support for the education, research, and extension programmes.

\section{REFERENCES}

1. CeRA. Consortium for e-Resources in Agriculture. 2011. http://www. cera.jccc.in/about/AboutCeRA.pdf (accessed on 2 February 2011).

2. Srivastava, Ranjana. Information use pattern of researchers in chemistry: A citation study. IASLIC Bulletin, 2002, 47(4), 185-92.

3. White, Sonya \& Creaser, Claire. Trends in scholarly journal prices 2000-2006: LISU Occasional Paper no. 37. Loughborough University. Leicestershire. 142 p. http://www.lboro.ac.uk/ departments/dis/lisu/pages/ publications/oup2.html, 2001. (accessed on 12.9.2007).

4. Xiaoyin-Zhang \& Haslam, Michaelyn. Movement toward a predominantly electronic journal collection. Library Hi Tech, 2005, 23(1), 82-89.

5. Vijayakumar, J.K. \& Vijayakumar, Manju. E-journals in a networked environment: its impact on academic libraries in the digital millennium. In Proceedings of National Seminar on Library Co-operation in a Networked World, edited by M. Bavakutty; M.C.K. Veeran \& Muhammed T.K. Sali, Kozhikode, 2002, pp. 75-82.

6. Majka, D.R. The 'great exchange': The economic promise and peril of the digital library. The Bottom Line: Managing Library Finances, 2000, 13(2), 68-73.
7. Bostick, Sharon L. Academic library consortia in the United States: An Introduction. Library Quarterly, 2001, 11(1), 6-13.

8. Francis, A.T. Library consortia model for country wide access of electronic journals and databases. In CALIBER-2005: Multilingual computing and information management in networked digital environment, edited by T.A.V. Murthy, et al. Paper presented at $3^{\text {rd }}$ International Convention on Automation of Libraries in Education and Research Institutions, 2-4 February 2005, Kochi. Inflibnet Centre, Ahmedabad. pp. 497-504.

9. Raman Nair, R. Agricultural information service for the farmers and the public: A study. ILA Bulletin, 2006, 42(3), 5-12.

10. National Agricultural Library. Advancing access to global information for agriculture. NAL Discussion Paper. Blue print for success: The National Agricultural Library, 2008-2012. 37 p. http://www.nal. (accessed on 23.9.2010).

11. UNESCO. A manual on how to create a website. UNESCO, New Delhi. 2005. http://portal.unesco.org/ ci/ en/ files/ 20938/ 11401731359 How_Create_ Website. pdf/ How_Create_Website.pdf. (accessed on 23.1.2011).

12. Corcoran, Janet. Writing and editing for the library website. FreePint Newsletter, 10 August 2006, 211. http://www. freepint. com/issues/ 100806.htm. (accessed on 17.6.2006).

13. Lebowitz, G. Library services to distant students: An equity issue. J. Acad. Librarianship, 1997, 23(4), 302-08.

14. Francis, A.T.; Razak, Abdul C. \& Kabir, Humayoon S. Role of information professionals as teachers and trainers in agricultural education: An experience of the Kerala agricultural university, India. In Preparing information professionals for leadership in the new age, edited by C. Khoo; D. Singh \& A.S. Chaudhry. Paper presented at the Asia-Pacific Conference on Library and Information Education and Practice (A-LIEP), 3-6 April 2006, Singapore. School of Communication \& Information, Nanyang Technological University, Singapore, 2006. pp. 642-44. 


\section{About the Author}

Dr A.T. Francis, presently working as the Head of the Library, College of Horticulture, Kerala Agricultural University (KAU), Thrissur. Before joining in KAU, he has worked in NPOL, DRDO, Cochin for six years; and JN College, Lakshadweep and Govt. Medical College, Thrissur for few months each.
After obtaining MCom (Financial Management), MLIS and NET/UGC, he did his doctoral studies in the Dept. of Computer Applications, Cochin University of Science and Technology in "Re-engineering and Re-defining University Libraries in the context of modern ICTs". He has published more than 20 articles and eight books/monographs. 